\title{
PELATIHAN PEMANDUAN BAKAT DAN MINAT OLAHRAGA BERBASIS TEKNOLOGI SPORT SEARCH PADA GURU PENJAS DI DAERAH PENAJAM PASER UTARA
}

\author{
Didik Cahyono*1, Muhammad Ramli Buhari², Jupri3 \\ 1,2,3Pendidikan Jasmani, Fakultas Keguruan dan Ilmu Pendidikan , Universitas Mulawarman, Indonesia \\ *e-mail: didikcahyono86@gmail.com , ramlipjkr@gmail.com², Adejf4466@gmail.com³
}

\begin{abstract}
Abstrak
Menemukan bakat seseorang merupakan sesuatu yang unik dan memerlukan caranya masing-masing. Susunan/struktur bakat adalah sangat komplek. Bakat adalah suatu potensi yang ditentukan secara genetis/keturunan, tidak stabil serta banyak dipengaruhi oleh keadaan lingkungan sekitar. Alat penemuan bakat diantaranya adalah untuk olahraga umum dengan sport search yang dikembangkan di Australia. Kemampuan mengoperasikan sport search sangat diperlukan bagi guru Penjas dalam penelusuran bakat dan minat anak didiknya. Kemampuan ini sangat diperlukan dalam usaha mencari bibit-bibit potensial olahraga yang ada di daerah.untuk menyelesaikan permasalahan yang dihadapi mitra, solusi yang ditawarkan adalah melakukan pelatihan kemampuan guru dalam mengoperasikan sport search. Desain materi pelatihan diharapkan dapat meningkatkan beberapa kemampuan guru, diantaranya adalah mampu menemukan bakat "terpendam" seorang anak di daerah Penajam Paser Utara. Peserta dalam pelatihan ini sebanyak 30 orang guru Pendidikan Jasmani Sekolah Dasar dan Sekolah Menengah Pertama. Pelatihan pemanduan bakat olahraga melalui aplikasi sport search ini sangat membantu guru PJOK dalam melakukan pemanduan bakat yang di miliki siswa khusunya dalam cabang olahraga. pengabdian pada masyarakat sebenarnya sangat diperlukan oleh para guru, terutama adanya pendampingan pasca kegiatan sehingga ada kesempatan bagi para guru untuk menerima umpan balik dari kegiatan aplikasi pengetahuan dan ketrampilan yang disampaikan.
\end{abstract}

Kata Kunci : minat dan bakat olahraga, sport search, pemanduan bakat olahraga

\section{PENDAHULUAN}

Pembibitan olahraga adalah tahapan penting yang dijadikan sebagai pondasi keberhasilan sistem pembinaan prestasi olahraga. Artinya, berhasil atau tidaknya sistem pembinaan prestasi olahraga prestasi sangat dipengaruhi oleh proses pembibitan yang dilakukan. Kesalahan dalam melakukan proses pembibitan akan menyebabkan terjadi ketidakmenentunya prestasi atau regenerasi tidak kontinyu, bahkan bisa mengakibatkan kegagalan dalam proses pembinaan prestasi olahraga. Sebagai akibatnya, atlet akan mengalami kesulitan dalam upaya meraih prestasi secara optimal.

Proses pengidentifikasian atlet yang berbakat, kemudian mengikutsertakannya dalam program latihan yang terorganisir dengan baik merupakan hal yang paling utama dalam olahraga. [1]Setiap orang dapat belajar menari, menyanyi, melukis namun sangat sedikit yang mencapai tingkat penguasaan yang tinggi. Maka dari itu dalam olahraga seperti juga dalam seni sangat penting untuk menemukan seseorang yang berbakat, menyeleksinya pada usia muda, memantaunya secara kontinyu, serta membantunya untuk mencapai tingkat penguasaan yang tertinggi. Sehubungan dengan hal tersebut di atas maka dibutuhkan sebuah alat bantu berupa tes yang dapat mengidentifikasi keberbakatan seorang anak di bidang olahraga sejak dini. Model struktur dari peningkatan bakat ini harus diatur sedemikian rupa sehingga ada interaksi yang 
erat antara penilaian latihan dan bakat/ketangkasan. [2]. Perlunya penanganan khusus untuk menemukan bakat seorang anak kalau tidak mau dikatakan "kebetulan".

Pemanduan bakat (talent identification) adalah suatu upaya yang dilakukan secara sistematik untuk mengidentifikasi seseorang yang berpotensi dalam olahraga, sehingga diperkirakan orang tersebut akan berhasil latihan dan dapat meraih prestasi puncak. [3]. Jika seorang calon atlet telah berpartisipasi dalam suatu cabang olahraga tertentu dan diketahui bakat dalam cabang olahraga tersebut, maka hal ini lebih tepat disebut pengembangan bakat (talent development). Adapun faktor-faktor yang mempengaruhi prestasi dalam olahraga adalah faktor dari luar dan faktor dari dalam. Faktor dari luar dapat diklasifikasikan menjadi faktor sosial dan non sosial (lingkungan alam dan peralatan). Faktor dari dalam terdiri dari fisik dan mental yang bersumber dari kualitas atlet itu sendiri.

Olahraga prestasi merupakan salah satu dari kegiatan olahraga dipandang sebagai profesi. Untuk mencapai prestasi olahraga yang tinggi tidaklah mudah, karena harus melalui proses pembinaan yang panjang, yaitu untuk 6 sampai 11 tahun kedepan. Dengan pembinaan dalam jangka waktu yang panjang, prestasi yang tinggi dapat dicapai jika didukung atlet yang berbakat. Meskipun dilakukan pembinaan dalam jangka panjang, jika atlet yang dibina tidak berbakat terhadap cabang olahraga yang dipelajari, maka prestasi yang tinggi tidak dapat dicapai. Hal tersebut karena bakat merupakan syarat mutlak agar mampu berprestasi secara maksimal. Adisasmita dan Syasifuddin (1996: 54) menyatakan bahwa "Bakat dan kemampuan akan menentukan prestasi seseorang, dimana prestasi yang sangat menonjol dalam satu bidang tertentu adalah mencerminkan bakat yang unggul dalam bidang tertentu".

Seseorang dikatakan berbakat dalam bidang olahraga apabila didalam dirinya terdapat ciri-ciri yang dapat dikembangkan dan dilatih menuju keberhasilan pencapaian prestasi yang tinggi dalam olahraga. Seorang atlet dalam suatu cabang olahraga memiliki usia keemasan atau usia pencapaian prestasi yang berbeda-beda, sebagai contoh menurut [4] dalam cabang olahraga tenis pencapaian prestasi pada usia 22-25 tahun, sepak bola pada usia 18-24, bolavoli pada usia 20-25, dan masih banyak lagi cabang olahraga yang memiliki usia keemasan sendiri-sendiri. Harre [5]mengemukakan bahwa pembinaan olahraga yang dilakukan secara sistematik, tekun, dan berkelanjutan, diharapkan akan dapat mencapai prestasi yang bermakna.

Pemanduan dan pengembangan bakat perlu dilakukan karena beberapa hal: 1) Mengingat atlet merupakan faktor utama yang menentukan dalam upaya mencapai prestasi, maka memilih atlet melalui pemanduan dan pengembangan bakat perlu dilakukan dengan sungguh-sungguh. 2) Proses untuk pencapaian prestasi dapat diefektifkan secara optimum, apabila atlet yang dilatih merupakan atlet pilihan yang memiiki potensi yang sesuai dengan tuntutan spesifikasi cabang olahraga yang bersangkutan. [6].

Adapun tujuan dari pemanduan bakat [7] adalah memprediksi dengan derajat yang tinggi, seberapa besar peluang seseorang untuk berhasil mencapai prestasi maksimalnya, dan apakah seorang atlet muda mampu untuk secara sukses menyelesaikan atau melewati program latihan dasar, untuk kemudian ditingkatkan latihannya menuju prestasi puncak. Semakin dini seseorang menampakkan bakatnya, semakin cepat dan besar kemungkinan baginya untuk memasuki tahap latihan puncak prestasi, sehingga puncak prestasinya bisa dicapai dalam usia yang lebih muda.

Menurut [8] Identifikasi bakat pada dasarnya memiliki dampak dan manfaat yaitu:

1. Menurunkan waktu yang diperlukan untuk mencapai prestasi yang tinggi dengan menyeleksi calon atlet yang berbakat dalam olahraga tertentu

2. Mengeliminasi volume kerja, energi dan memisahkan bakat yang tinggi bagi pelatih. Keefektifan latihan dapat dicapai terutama bagi calon atlet yang memiliki kemampuan tinggi.

3. Meningkatkan daya saing dan jumlah atlet mencapai tingkat prestasi tinggi.

4. Meningkatkan kepercayaan diri atlet, karena perkembangan prestasi, tampak makin drastis dibanding dengan atlet-atlet lain yang memiliki usia sama yang tidak mengalami seleksi.

5. Secara tidak langsung mempermudah penerapan latihan. 
Tes identifikasi bakat yang dapat digunakan adalah tes model sport search. [9]. Adapun tujuan dari masing-masing tes tersebut adalah:

1) Tinggi badan. Tinggi badan adalah jarak vertikal dari lantai ke ujung kepala (vertex). Tinggi badan ini merupakan faktor penting di dalam berbagai cabang Olahraga. Misalnya, para pemain bola basket dan atlet dayung (rower), biasanya memiliki tubuh yang tinggi, sedangkan pemain senam seringkali badannya kecil.

2) Tinggi duduk.Tinggi duduk adalah jarak vertikal dari alas permukaan tempat testi duduk sehingga bagian atas (vertex) Kepala. Pengukuran ini meliputi panjang togok, leher, dan sampai panjang kepala. Perbandingan tinggi duduk dengan tinggi badan pada saat berdiri adalah berkaitan dengan penampilan dalam berbagai cabang olahraga. Misalnya, dalam lompat tinggi, perbandingannya adalah tungkai lebih panjang daripada togok

3) Berat badan. Berat badan berkaitan erat dengan beberapa cabang olahraga yang membutuhkan tubuh yang ringan, seperti senam, apabila dibandingkan dengan cabang olahraga yang memerlukan berat badan lebih berat, seperti olahraga lempar dalam atletik.

4) Rentang lengan. Rentang lengan adalah jarak horizontal antara ujung jari tengah dengan lengan terentang secara menyamping setinggi bahu. Rentang lengan meliputi lebar kedua bahu.dan panjang anggota badan bagian atas (tangan). Rentang lengan berkaitan erat dengan olahraga, seperti dalam olahraga dayung dan melempar, yang terentang lengan yang lebar, karena sangat bermanfaat bagi penampilannya.

5) Lempar tangkap bola tenis. Tes lempar-tangkap bola tennis bertujuan untuk mengukur kemampuan testi melempar bola tennis dengan ayunan dari bawah lengan (underarm) kearah sasaran dan menangkapnya dengan satu tangan dan mata berkaitan dengan penampilan dalam berbagai permainan bola yang bersifat beregu yang menuntut atlet untuk dapat membawa, menggiring dan menangkap bola.

6) Lempar bola basket.Tes melempar bola basket dirancang untuk mengukur kekuatan tubuh bagian atas. Olahraga yang membutuhkan kekuatan yang tinggi pada tubuh bagian atas, antara lain gulat dan angkat besi.

7) Loncat Tegak. Tes loncat tegak adalah mengukur kemampuan untuk meloncat dalam arah vertikal. Daya ledak kedua kaki berkaitan dengan penampilan dalam olahraga, misalnya bola basket, bola voli dan sepak bola Australia (Australian Football)

8) Lari bolak balik 5 meter. Kelincahan (kemampuan untuk mengubah arah tubuh secara cepat sambil bergerak) merupakan komponen penting di dalam kebanyakan olahraga beregu, misalnya squash dan tenis

9) Lari cepat 40 meter. Kemampuan lari dengan cepat dari posisi tak bergerak dibutuhkan di dalam permainan beregu, misalnya bola keranjang dan permainan bola kriket. Kecepatan juga penting di dalam beberapa cabang olahraga yang membutuhkan ledakan aktifitas yang pendek dengan intensitas tinggi.

10) Lari multitahap. Kesegaran aerobik merupakan komponen penting dari berbagai cabang olahraga berbasiskan daya tahan (endurance). Misalnya olahraga renang jarak jauh, bersepeda dan lari jarak jauh. Kebanyakan permainan beregu juga mempersyaratkan kesegaran aerobik karena para pemain harus senantiasa bergerak selama jangkau waktu yang lama. Lari bolak balik (Shuttle Run) atau Lari Multitahap (Multistage Fitness Test) digunakan untuk menilai kesegaran aerobik. [8]

Berdasarkan pendapat yang telah dikemukan diatas jelas bahwa identifikasi bakat sangat penting dan besar sekali manfaatnya bagi perkembangan olahraga di masa yang akan datang. Oleh sebab itu pemanduan bakat pada anak Sekolah Dasar (SD) sangat penting untuk dilakukan.

Sasaran dalam pemanduan bakat adalah ditemukannya bakat anak-anak sejak usia dini. Tahap pertama mengidentifikasi bakat anak-anak sekolah umur dibawah 12 tahun dilakukan dengan tes yang sederhana. Guru pendidikan jasmani memiliki peranan penting terkhusus dalam melakukan proses identifikasi pada tahap awal. Oleh karena itu dibutuhkan pelatihan 
pemanduan bakat dan minat olahraga berbasis sport search bagi guru penjas di daerah Penajam Paser Utara.

Berdasarkan hasil analisis situasi dan diskusi dengan mitra di daerah Babulu, Waru, Sepaku dan Penajam pemanduan bakat yang biasa dilakukan adalah metode pemanduan bakat secara alami. Metode seleksi alami ini dipertimbangkan sebagai metode dengan pendekatan normal dalam pengembangan potensi atlet. Metode ini berasumsi bahwa atlet yang mengikuti aktivitas olahraga merupakan hasil pengaruh lokal (tradisi sekolah, keinginan orang tua, ataupun keinginan kelompok sepermainannya), sehingga pencapaian atas perubahan prestasi atlet ditentukan atau tergantung pada pilihan yang bersifat alami.

Perubahan prestasi atlet sering kali sangat lamban, hal ini disebabkan atlet telah melakukan pilihan cabang olahraga yang tidak tepat baginya. Sehingga perubahan kemampuan seorang atlet ditentukan oleh seleksi alamiah yang tergantung pada berbagai faktor, individual, kebetulan, seorang atlet dalam mengambil cabang yang sesuai dengan bakatnya. Maka dari itu sering terjadi perkembangan kemampuan atlet sangat lambat, diakibatkan karena pemilihan cabang olahraga yang tidak sesuai. Oleh karena itu berdasarkan hasil analisis situasi dan diskusi dengan mitra tersebut dapat dirumuskan beberapa masalah, yaitu :

1. Perlu metode pemanduan bakat secara ilmiah

2. Pemanduan bakat berbasis IT

3. Metode yang bisa mengakomodir jumlah anak yang banyak (screening) dengan meminimalkan waktu yang singkat.

4. Tidak pernah diberikan pelatihan pemanduan bakat berbasis sport search.

5. Hasilnya bisa digunakan sebagai data awal bagi guru Penjas/pelatih cabor sebelum menetapkan latihan.

6. Hasil analisis data yang diperoleh lebih akurat

\section{SOLUSI DAN TARGET LUARAN}

Untuk menyelesaikan permasalahan yang dihadapi, solusi yang ditawarkan adalah melakukan pelatihan kemampuan guru dalam mengoperasikan pemanduan bakat dan minat olahraga berbasis "sport search". Metode sport search ini, merupakan metode pemilihan calon atlet yang dilakukan pelatih terhadap para anak/remaja prospektif didukung dengan bukti-bukti bahwa calon atlet mempunyai kemampuan alami untuk cabang olahraga yang dilatihkan. Beberapa hasil penelitian menunjukkan bahwa waktu yang diperlukan untuk meraih prestasi puncak bagi calon atlet yang dipilih secara ilmiah lebih singkat, bila dibandingkan dengan calon atlet yang dipilih melalui metode alami. [7]. Berdasarkan pernyataan di atas, metode pemilihan calon atlet yang dilakukan secara ilmiah sudah selayaknya mendapatkan pertimbangan secara ketat, khususnya bagi cabang olahraga yang memerlukan persyaratan tinggi dan berat badan (seperti: bola basket, bola voli, sepak bola, mendayung, lempar lembing, dsb), Hal yang sama dapat pula ditujukan pada cabang olahraga lain yang memerlukan kecepatan, waktu reaksi, koordinasi dan power yang dominan (seperti: lari cepat, judo, hoki, nomor lompat dalam atletik, dsb).

Dengan bantuan ilmuwan olahraga, kualitas yang dibutuhkan dapat dideteksi, dan sebagai hasil pengujian ilmiah yang dilakukan oleh profesional yang berkompeten di bidangnya, calon atlet berbakat dapat dipilih secara ilmiah dan selanjutnya dapat diarahkan pada cabang olahraga yang sesuai. Oleh karena ini materi pelatihan meliputi hal berikut:

1. Mengenalkan model pemanduan bakat dan minat olahraga berbasis sport search

2. Bimbingan praktek cara penggunaan aplikasi sport search

3. Mengenalkan instrument tes pemanduan bakat

4. Mempraktekkan bentuk tes pemanduan bakat

5. Menginput hasil tes pemanduan bakat dengan menggunakan aplikasi sport search

6. Menganalisa hasil tes pemanduan bakat dengan menggunakan aplikasi sport search

Desain materi pelatihan diharapkan dapat meningkatkan beberapa kemampuan guru, diantaranya sebagai berikut: 
1. Mampu mengoperasikan pemanduan bakat dan minat olahraga berbasis sport search

2. Mampu melaksanakan praktikum pemanduan bakat dan olahraga berbasis sport search sesuai tahapan-tahapannya

3. Mampu mengenal instrument tes pemanduan bakat

4. Mampu mempraktekkan bentuk tes pemanduan bakat

5. Mampu menginput hasil tes pemanduan bakat dengan menggunakan aplikasi sport search

6. Mampu menganalisa hasil tes pemanduan bakat dengan menggunakan aplikasi sport search

\section{METODE DAN PELAKSANAAN}

Dalam kegiatan pelaksanaan pengabdian masyarakat ini di laksanakan pada saat sedang dalam kondisi pandemi covid - 19, seperti kita ketahui bahwa dalam kegiatan di masa pandemi ini di sarankan untuk tetap di laksanakan dengan cara virtual meeting dan workshop, Metode yang digunakan dalam pelatihan ini adalah dengan kegiatan webinar melalui aplikasi zoom meeting adapun metodenya sebagai berikut:

1. Metode Ceramah

Metode ceramah digunakan untuk menjelasakan teori-teori dasar dan pengetahuan umum tentang model pemanduan bakat dan minat berbasis sport search. Metode ini diberikan pada tiap awal pembahasan pokok bahasan, yang bertujuan untuk memberikan dasar-dasar teori tiap pokok bahasan baru melalui webinar secara virtual.

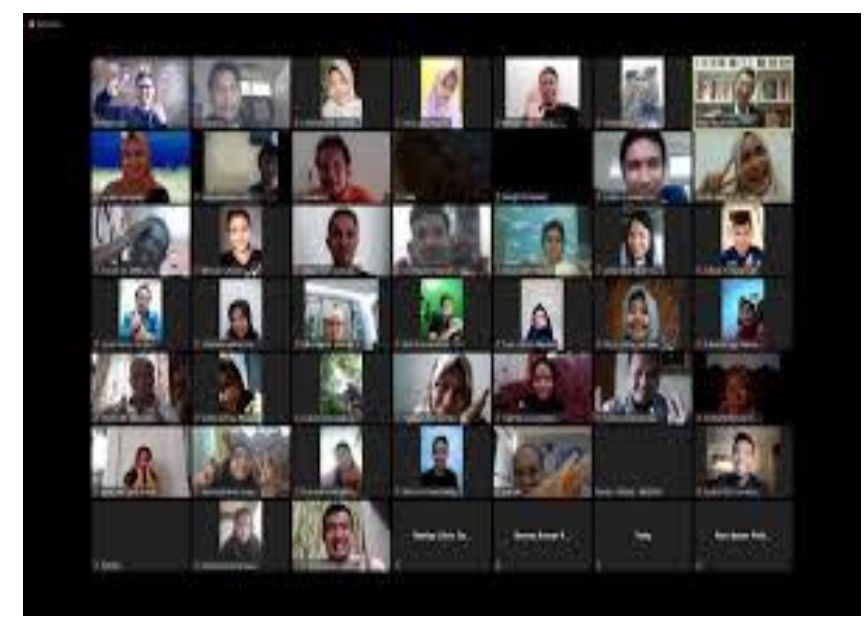

Gambar 1. Metode ceramah

2. Metode Demonstrasi secara virtual

Metode ini diberikan untuk menjelaskan penggunaan fitur pada sport search dan Akses Internet. Pada materi ini mendemostrasikan fitur yang ada pada model pemanduan bakat dan minat berbasis sport search, serta bagaimana mengakses ke aplikasi sport search. Diharapkan dengan metode ini pemahaman peserta terhadap masing-masing materi makin mendalam. 


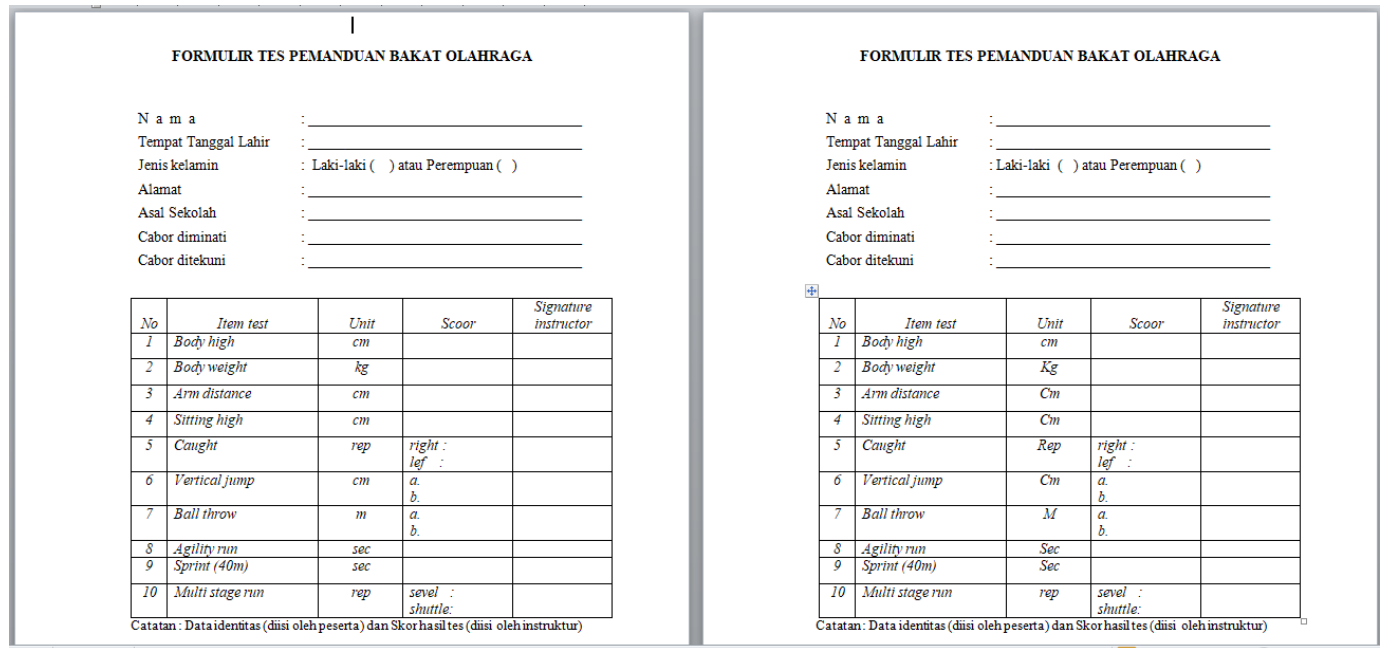

Gambar 2. Metode demonstrasi

3. Metode Praktik

Pada metode ini peserta mempraktikkan secara langsung dengan di pandu oleh narasumber secara langsung melalui virtual meeting, semua materi yang sudah didapatkan sebelumnya. Metode ini digunakan untuk mengetahui sejauhmana tiap peserta mampu mengoperasikan model pemanduan bakat dan minat berbasis sport search.

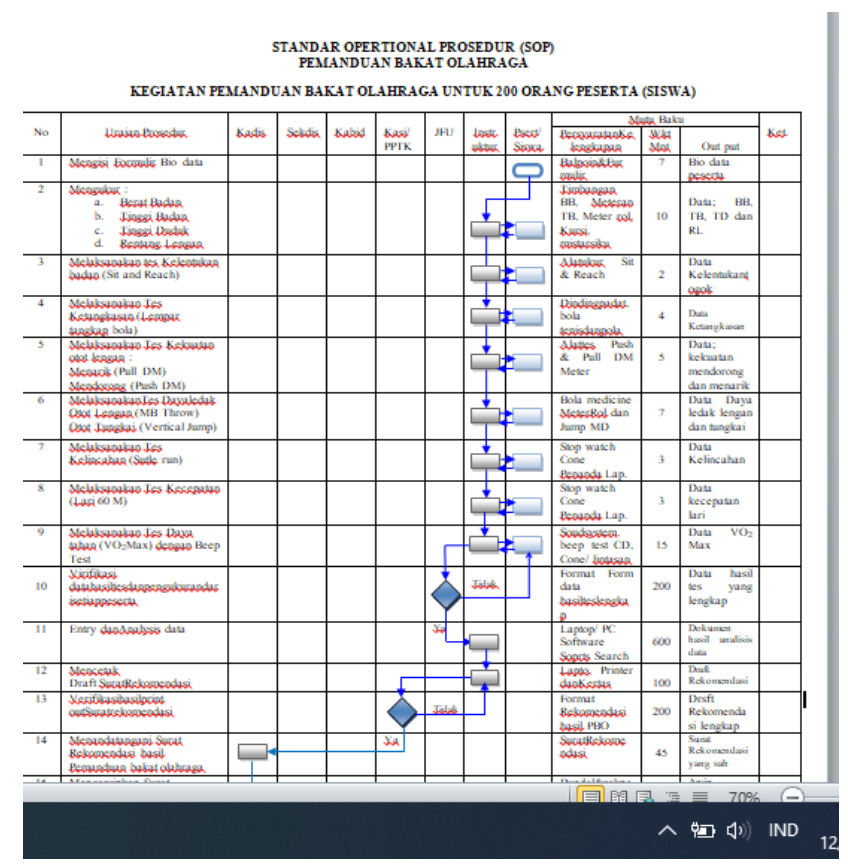

Gambar 3. Metode Praktik

\section{HASIL DAN PEMBAHASAN}

Mengingat masih dalam suasana pandemi maka kegiatan ini di laksanakan secara virtual meeting, melalui kegiatan webinar yang berjudul pemanduan bakat olahraga melalui aplikasi sport search di masa pandemi, dalam webinar tersebut lebih di fokuskan kepada pemahaman dan praktek langsung pemanduan bakat olahraga melalui teknologi sport search. poin yang bisa di ambil dalam pelaksanaaan kegiatan pngabdian masyarakat ini adalah Pelatihan pemanduan bakat olahraga melalui aplikasi sport search ini sangat membantu guru PJOK dalam melakukan 
pemanduan bakat yang di miliki siswa khusunya dalam cabang olahraga. pengabdian pada masyarakat sebenarnya sangat diperlukan oleh para guru, terutama adanya pendampingan pasca kegiatan sehingga ada kesempatan bagi para guru untuk menerima umpan balik dari kegiatan aplikasi pengetahuan dan ketrampilan yang disampaikan.

\section{KESIMPULAN}

Berdasarkan hasil pelaksanaan pengabdian masyarakat yang telah dilakukan maka bisa disimpulkan hal-hal sebagai berikut:

a. Kegiatan PKm ini bisa memberikan manfaat langsung kepada para guru PJOK dalam melakukan pemandian bakat yang dimiliki oleh siswa sehingga memperoleh wawasan dan pengetahuan yang lenih terkait bakat olahraga yang di miliki.

b. Kegiatan PKm dapat dijadikan sarana berinovasi dalam usaha mengembangkan bakat olahraga siswa agar dapat lebih berprestasi di dalam olahraga.

c. Meningkatkan kerjasama lanjutan antara Program studi Pendiidikan jasmani FKIP Universitas Mulawarman dengan para guru PJOK. Yang ada di seluruh wilayah kalimantan timur.

Sebagai saran, kepada peserta sangat di sarankan untuk terus mengembangkan dan berinovasi dalam mencari bakat - bakat yang di miliki oleh siswa agar prestasi siswa menjadi lebih baik serta kepada universitas agar senantiasa bisa memberikan kesempatan dan dukungan yang lebih dalam melaksanakan program ini supaya bisa menjangkau guru PJOK yang ada di wilayah Kalimantan Timur dlaam pelatihan ini

\section{DAFTAR PUSTAKA}

[1] S. Sukendro and M. Ihsan, "Identifikasi Bakat Cabang Olahraga Dengan Metode Sport Search Pada Ektrakurikuler Sepakbola SMP Negeri 16 Kota Jambi," Jorpres Uurnal Olahraga Prestasi), vol. 14, no. 1, pp. 46-63, 2018, doi: 10.21831/jorpres.v14i1.19980.

[2] M. Syafei, D. R. Budi, M. N. H. Kusuma, and A. D. Listiandi, "Identifikasi Keberbakatan Olahraga Metode Australian Sport Search Pada Anak Sekolah Dasar," Phys. Act. J., vol. 1, no. 2, pp. 99-106, 2020.

[3] H. Bramantha, "Identifikasi bakat olahraga dengan menggunakan metode sport search pada siswa putra kelas v SDN 3 Mangaran Kabupaten Situbondo," J. Cermin P3M UNARS, vol. 1, no. 2, pp. 30-35, 2017.

[4] G. et al Utomo, "Journal of Sport Sciences and Fitness - PDF Download Gratis.pdf," vol. 5, no. 2, pp. 6-10, 2012.

[5] P. Bakat et al., "Pemanduan Bakat Dan Minat Cabang Olahraga Melalui Metode Sport Search Pada Siswa Smp Negeri Se Kecamatan Karanganyar Kabupaten Demak Tahun 2013/2014," E-Jurnal Phys. Educ., vol. Sport, no. Health and Recreation, pp. 1686-1705, 2015, doi: 10.15294/active.v4i3.4677.

[6] N. A. Saputro, J. Pendidikan, J. Kesehatan, and F. I. Keolahragaan, "Minat Dan Motivasi Kegemaran Olahraga Terhadap Hasil Tes Pemanduan Bakat Sport Search," Act. - J. Phys. Educ. Sport. Heal. Recreat., vol. 3, no. 10, pp. 1317-1321, 2014, doi: 10.15294/active.v3i10.3647.

[7] E. Purnomo, L. Nini, Y. T. J. Samodra, and E. Purnomo, "Penerimaan Atlet Atletik di Pusat Pendidikan dan Latihan Olahraga Pelajar (PPLP)," vol. 9, no. 2, pp. 39-51, 2020.

[8] W. Wahjoedi, I. P. P. Adi, and ..., "Pelatihan Penerapan Iptek Keolahragaan Pada Pembinaan Cabor Panjat Tebing," Semin. Nas. ..., pp. 621-628, 2017.

[9] Saiful Millah, "Dengan Metode Sport Search Pada Lucky Tennis School Jakarta Tahun 2016 ," Unnes, 2016.

[10] Z. Arifin, I. S. Fallo, and P. Sastaman, "Identifikasi bakat olahraga siswa sekolah dasar di Pontianak Barat," J. Pendidik. Olahraga, vol. 6, no. 2, pp. 129-139, 2017. 
